\begin{tabular}{|c|c|}
\hline 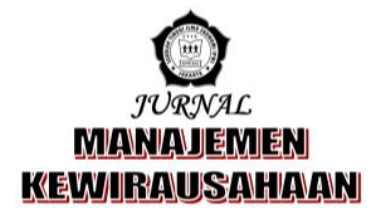 & $\begin{array}{r}\text { p-ISSN 1858-1048 } \\
\text { e-ISSN 2654-9247 } \\
\text { http://ejurnal.stieipwija.ac.id/index.php/imk } \\
\text { DOI: http://dx.doi.org/10.33370/imk.v16i1.268 } \\
\text { Jurnal Manajemen Kewirausahaan Vol. 16 No. 01 - Juni } 2019 \\
\text { Submit: 26 Des 2018; Review: 17 Jun 2019; Publish: 30 Jun } 2019\end{array}$ \\
\hline
\end{tabular}

\title{
PENGARUH PERENCANAAN, EFEKTIVITAS, DAN OPTIMALISASI DAYA SERAP ANGGARAN TERHADAP KINERJA PEGAWAI KEMENTERIAN PERTAHANAN
}

\author{
Oleh: \\ Sugoto Sulistyono1), I Gusti Ayu Arminiati2) \\ leosugoto@gmail.com ${ }^{1}$, igaarminati@yahoo.co.id $\left.{ }^{2}\right)$ \\ Sekolah Tinggi Ilmu Ekonomi IPWI Jakarta
}

\begin{abstract}
ABSTRAK
Perencanaan, efektivitas, dan optimalisasi daya serap anggaran merupakan tiga dari beberapa faktor yang diduga relatif besar dalam mempengaruhi kinerja pegawai pada Direktorat Jenderal Strategi Pertahanan Kementerian Pertahanan. Untuk membuktikan pengaruh ketiganya maka dilakukan penelitian ini dengan tujuan untuk mengetahui pengaruh perencanaan, efektivitas dan optimalisasi daya serap anggaran pada Direktorat Jenderal Strategi Kementerian Pertahanan.

Penelitian dilakukan di Direktorat Jenderal Strategi Pertahanan Kementerian Pertahanan dengan mengambil 50 responden, sebagai sampel penelitian waktu penelitian selama 3 bulan. Pengambilan data dilakukan dengan instrumen kuesioner tertutup lima skala penilaian. Penelitian dilakukan secara kuantitatif yaitu dengan mendeskripsikan data penelitian dan melakukan analisis inferensi. Analisis regresi linier ganda dan koefisien determinasi ganda digunakan sebagai alat analisis sedangkan pengujian hipotesis dilakukan dengan uji-t dan uji-F yang diolah dengan software SPSS 22. Dari data-data yang telah mempengaruhi uji validitas, uji reliabilitas, dan uji asumsi klasik diperoleh persamaan regresi sebagai berikut: $Y=7,078+0,306 X 1+0,406 X 2+$ $0.490 X 3$.

Penelitian menghasilkan empat temuan utama sesuai dengan hipotesis yang diajukan, yaitu: 1) Perencanaan memiliki pengaruh terhadap kinerja pegawai dengan arah positif yang mempunyai nila sebesar 0,306 atau 30,6\%; 2) Efektivitas memiliki pengaruh terhadap kinerja pegawai dengan arah positif yang mempunyai nilai sebesar 0,406 atau 40,6\%; 3) Optimalisasi daya serap anggaran memiliki pengaruh terhadap kinerja pegawai dengan arah positif yang mempunyai nilai sebesar 0,490 atau 40,9\%. Berdasarkan hasil temuan tersebut maka untuk meningkatkan kinerja pegawai disarankan agar dilakukan upaya memperbaiki percanaan, efektivitas dan optimalisasi daya serap anggaran
\end{abstract}

Kata Kunci: perencanaan, efektivitas, optimalisasi daya serap anggaran

\section{PENDAHULUAN}

Kementerian Pertahanan Republik Indonesia, merupakan salah satu instansi tertua yang dimiliki oleh Indonesia. Departemen Pertahanan masih belum dapat berjalan secara efektif, sehingga dibentuk Kementerian Keamanan Rakyat untuk menggantikan Departemen Pertahanan. Kementerian Keamanan Rakyat tersebut menjalankan 
fungsi pertahanan negara sampai dengan tahun 1962, dan kemudian fungsi pertahanan negara kembali berada di bawah Departemen Pertahanan.

Selanjutnya, mulai dari era Kabinet Pembangunan II dan seterusnya, fungsi pertahanan dan keamanan selalu disatukan dan berada di bawah Departemen Pertahanan dan Keamanan.

Kementerian Pertahanan, baru sekali pada tahun 2013 mendapatkan penilaian Wajar Tanpa Pengecualian (WTP).

Paling sering terjadi pelaksanaan pekerjaan tidak sesuai target, semisal tahun anggaran 2016 ada 459 pekerjaan yang tidak selesai sampai akhir tahun anggaran.

Pada tahun 2015 ada perubahan sistem dalam Standar Akuntansi Pemerintahan, yaitu dari cash basis menjadi accrual basis. Dengan perubahan itu, opini di Kementerian Pertahanan dan TNI menjadi WDP dan pada tahun 2016 belum beranjak dari opini WDP. Dalam hasil pemeriksaan tahun 2016, masih ada permasalahan dalam sistem pengendalian intern.

Hasil pemeriksaan BPK RI terhadap Laporan Keuangan Kemhan pada tahun 2014 adalah Wajar Tanpa Pengecualian Dengan Paragraf Penjelasan (WTP DPP). Hasil tersebut mengalami penurunan jika dibandingkan tahun sebelumnya. Oleh karenanya, dalam rangka meningkatkan opini BPK RI, Menhan mengharapkan seluruh jajaran Kemhan dapat bekerjasama dan membantu proses pemeriksaan yang akan dilaksanakan oleh Tim BPK RI serta memberikan penjelasan yang lengkap dan memadai. Selain itu, seluruh jajaran Kemhan agar melaksanakan upaya perbaikan sesuai rekomendasi yang diberikan oleh Tim BPK RI pada pemeriksaan terdahulu terhadap proses penyusunan Laporan Keuangan.

Direktorat Jenderal Strategi Pertahanan Kemhan dalam melaksanakan tugas mengacu pada Rencana Strategis (Renstra) dan Rencana Kerja (Renja) yang telah ditetapkan dan ditindaklanjuti dengan tahapan penyusunan program dan anggaran sampai dengan penetapan program kerja dan anggaran. Kinerja Ditjen Strahan Kemhan dapat dianalisa dan dievaluasi yang secara rutin dilakukan melalui pelaporan baik bulanan, triwulan, semester maupun tahunan.

Mengingat fungsi anggaran negara sebagaimana tersebut dalam UU No. $17 / 2003$ adalah alat akuntabilitas, manajemen, dan kebijakan ekonomi. Sebagai instrumen kebijakan ekonomi, anggaran negara yang mencakup penerimaan dan pengeluaran negara berfungsi untuk mewujudkan pertumbuhan dan stabilitas perekonomian serta pemerataan pendapatan dalam rangka mencapai tujuan bernegara permasalahan mengenai minimnya daya serap anggaran di lingkungan kementerian atau lembaga kerap kali dituding sebagai buruknya kinerja birokrasi. Karena dengan kegagalan target daya serap anggaran akan berakibat hilangnya manfaat belanja. Nah, itu berarti bahwa dana yang telah dialokasikan dalam belanja negara ternyata tidak semuanya dapat dimanfaatkan, ini berarti terjadi iddle anggaran. Bisa dibayangkan seandainya uang yang tersimpan tersebut bisa dimanfaatkan untuk kepentingan yang lebih besar. Tentu pencapaian tujuan nasional kita akan mudah untuk dilakukan.

Rendahnya tingkat penyerapan anggaran di Indonesia merupakan fenomena yang hampir selalu terjadi setiap tahun baik itu di tingkat Kementerian atau Lembaga maupun Tingkat Daerah kendatipun undangundang tentang keuangan negara atau Anggaran Pendapatan Belanja Negara (APBN) disusun sesuai kebutuhan penyelenggara pemerintahan negara, namun pelaksanaan tata kelola pemerintahan masih ditemukan masalah lambatnya penyerapan dana APBN oleh kementerian negara atau lembaga dan satuan kerja (satker) di bawahnya.

Daya serap anggaran dalam Kementerian Pertahanan khususnya pada Direktorat Jenderal Strategi Pertahanan dalam semester I tahun 2018 pada posisi yang sama yaitu baru sebesar 50 persen. Daya serap tersebut hanya diprioritaskan untuk kegiatan di luar 
program anggaran Direktorat Jenderal Strategi Pertahanan. Oleh karena itu dalam rangka persiapan pelaksanaan anggaran dan meningkatkan kualitas pengelolaan APBN Kementerian Pertahanan tahun 2018, perlu segera dilakukan peningkatan kualitas pengelolaan APBN yang meliputi pelaksanaan dan evaluasi.

\section{TUJUAN PENELITIAN}

- Pengaruh perencanaan terhadap kinerja pegawai pada Kantor Direktorat Jenderal Strategi Pertahanan.

- pengaruh efektivitas terhadap kinerja pegawai pada Kantor Direktorat Jenderal Strategi Pertahanan.

- Optimalisasi daya serap anggaran berpengaruh terhadap kinerja pegawai pada Kantor Direktorat Jenderal Strategi Pertahanan.

\section{TELAAH LITERATUR DAN PENGEMBANGAN HIPOTESIS Manajemen Keuangan}

Sutrisno (2009:2) manajemen keuangan sebagai segala aktivitas perusahaan yang bersangkutan dengan usaha-usaha mendapatkan dana perusahaan dengan biaya yang murah serta usaha untuk menggunakan dana dan mengalokasikan dana tersebut secara efisien. Selanjutnya menurut Bringham dalam Kasmir (2010:7) dinyatakan bahwa manajemen keuangan adalah seni (art) dan ilmu (science), untuk me-manage uang yang meliputi proses, intuisi/lembaga, pasar, dan instrument yang terlibat dengan masalah transfer uang di antara individu, bisnis, dan pemerintah. Kemudian menurut James C. Van Horne \& John M. Wachowichz Jr (2012:2), mengemukakan bahwa manajemen Keuangan berkaitan dengan perolehan, pendanaan dan manajemen asset dengan didasari beberapa tujuan umum.

Dari beberapa pengertian tersebut dapat disimpulkan bahwa aktivitas manajemen keuangan berkaitan erat dengan pengelolaan keuangan perusahan, termasuk lembaga yang berhubungan erat dengan sumber pendanaan dan investasi keuangan perusahan serta intrumen keuangan.

\section{Perencanaan}

Fungsi perencanaan menurut Davis (2003:48) terbagi atas:

1. Rencana strategis, menggambarkan fokus bisnis utama perusahaan untuk jangka panjang.

2. Perencanaan taktis, merupakan rencana-rencana perusahaan yang berskala lebih kecil yang konsisten dengan rencana strategis.

3. Perencanaan operasional, menyusun metode-metode yang akan segera digunakan.

4. Perencanaan darurat, merupakan rencana-rencana alternatif yang di kembangkan untuk menghadapi berbagai kondisi bisnis yang mungkin terjadi.

Di samping itu manfaat anggaran juga akan memberitahukan kepada karyawan apa yang diharapkan dari mereka, memungkinkan penilaian prestasi kerja dapat dilakukan dan juga dijadikan sarana untuk menghubungkan sasaran dari semua departemen yang akan dipadukan menjadi sasaran keseluruhan. Setiap perencanaan baik dalam organisasi pemerintahan maupun organisasi manajerial menyusun perencanaan untuk mencapai tujuan organisasi. Dalam setiap perencanaan akan terlihat fungsi dari perencanaan itu sendiri dan juga faktor-faktor yang turut menentukan dalam menentukan perencanaan.

\section{Efektivitas}

Menurut Effendy (2008:14) mendefinisikan efektivitas sebagai berikut komunikasi yang prosesnya mencapai tujuan yang direncanakan sesuai dengan biaya yang dianggarkan, waktu yang ditetapkan dan jumlah personil yang ditentukan. Efektivitas menurut pengertian di atas mengartikan bahwa indikator efektivitas dalam arti tercapainya sasaran atau tujuan yang telah ditentukan sebelumnya merupakan sebuah pengukuran dimana suatu target telah tercapai sesuai dengan apa yang telah direncanakan. 
Pengertian lain menurut Susanto (2005:156), efektivitas merupakan daya pesan untuk mempengaruhi atau tingkat kemampuan pesan-pesan untuk mempengaruhi. Menurut pengertian Susanto di atas, efektivitas bisa diartikan sebagai suatu pengukuran akan tercapainya tujuan yang telah direncanakan sebelumnya secara matang. Efektivitas merupakan suatu ukuran yang memberikan gambaran seberapa jauh target dapat tercapai. Pendapat tersebut menyatakan bahwa efektivitas merupakan suatu ukuran yang memberikan gambaran seberapa jauh target yang telah ditetapkan sebelumnya oleh lembaga atau organisasi dapat tercapai.

Lebih lanjut menurut Agung Kurniawan (2005:109) mendefinisikan efektivitas, sebagai berikut efektivitas adalah kemampuan melaksanakan tugas, fungsi (operasi kegiatan program atau misi) daripada suatu organisasi atau sejenisnya yang tidak adanya tekanan atau ketegangan diantara pelaksanaannya.

Upaya mengevaluasi jalannya suatu organisasi, dapat dilakukan melalui konsep efektivitas. Konsep ini adalah salah satu faktor untuk menentukan apakah perlu dilakukan perubahan secara signifikan terhadap bentuk dan manajemen organisasi atau tidak. Dalam hal ini efektivitas merupakan pencapaian tujuan organisasi melalui pemanfaatan sumber daya yang dimiliki secara efisien, ditinjau dari sisi masukan (input), proses, maupun keluaran (output). Dalam hal ini yang dimaksud sumber daya meliputi ketersediaan personil, sarana dan prasarana serta metode dan model yang digunakan. Suatu kegiatan dikatakan efisien apabila dikerjakan dengan benar dan sesuai dengan prosedur sedangkan dikatakan efektif bila kegiatan tersebut dilaksanakan dengan benar dan memberikan hasil yang bermanfaat.

\section{Daya Serap Anggaran}

Pada saat ini Keppres yang berlaku adalah Keppres nomor 42 tahun 2002. Kinerja manajemen publik akan dinilai berdasarkan pencapaian target anggaran, berapa yang berhasil dicapai. Penilaian kinerja dilakukan dengan menganalisis simpangan kinerja aktual dengan yang dianggarkan (Mardiasmo, 2009). Dalam teori ekonomi makro, belanja pemerintah merupakan salah satu elemen untuk menjaga pertumbuhan ekonomi suatu negara. Belanja pemerintah, khususnya belanja barang dan jasa, merupakan salah satu komponen utama yang membentuk Produk Domestik Bruto (PDB) atau Gross Domestic Product (GDP).

Namun demikian penyerapan anggaran tidak diharuskan mencapai $100 \%$, tetapi penyerapan anggaran diharapkan mampu memenuhi setidaktidaknya lebih dari $80 \%$ anggaran yang telah ditetapkan. Rasio realisasi penyerapan belanja Kementerian atau Lembaga terhadap pagu anggaran belanja merupakan suatu bentuk indikator efektivitas belanja negara. Selain itu kebijakan APBN diharapkan dapat merespon dinamika rakyat baik yang terkait dengan perkembangan perekonomian secara luas, maupun kehidupan rakyat itu sendiri, sehingga diperlukan kebijakan fiskal yang bersifat kleksibel (Rahayu, 2011).

Dalam kerangka penganggaran berbasis kinerja, sebenarnya penyerapan anggaran bukan merupakan target alokasi anggaran. Namun, mengingat kondisi perekonomian kita saat ini variabel dominan pendorong pertumbuhannya adalah faktor konsumsi, maka belanja pemerintah yang ekspansif turut menjadi penentu pertumbuhan tersebut. Sehingga kegagalan target penyerapan anggaran bisa mengganggu upaya peningkatan pertumbuhan ekonomi. Secara empirik, hal ini juga telah dibuktikan melalui penelitian yang dilakukan Bakara (2000) \& Akadira (2010) yang mengungkapkan bahwa perencanaan yang baik akan sangat membantu tingkat penyerapan. Karenanya tidaklah berlebihan apabila upaya pengawasan terhadap belanja Pemerintah sudah dimulai sejak tahap perencanaan. 


\section{Kinerja}

Kinerja merupakan suatu wujud dari keberhasilan yang dicapai oleh seorang pegawai atas pekerjaannya untuk mencapai tujuan yang telah ditetapkan oleh organisasi. Kinerja sangat dipengaruhi oleh kebijakan atasan dalam menempatkan posisi pegawai sesuai dengan kemampuan yang dimilikinya. Mangkunegara (2000) mengartikan kinerja sebagai hasil kerja secara kualitas dan kuantitas yang dicapai oleh seorang pegawai dalam melaksanakan tugasnya sesuai dengan tanggung jawab yang diberikan kepadanya.

Secara lebih dalam kinerja juga dijelaskan sebagai pencapaian pegawai diluar tupoksi yang melekat padanya, sehingga dapat menciptakan produktifitas yang lebih baik. Hal tersebut sejalan dengan pendapat Cushway (2002), kinerja adalah menilai bagaimana seseorang telah bekerja dibandingkan dengan target yang telah ditentukan. Dalam kajian tersebut, tindakan nyata dari setiap pegawai merupakan suatu proses untuk mencapai kinerja yang baik. Mink (1993:76) mengemukakan pendapatnya bahwa individu yang memiliki kinerja yang tinggi memiliki beberapa karakteristik.

\section{Pengembangan Hipotesis \\ Pengaruh Perencanaan terhadap Kinerja Pegawai}

Perencanaan anggaran merupakan rencana kegiatan yang terdiri dari sejumlah target yang akan dicapai oleh para pelaksana anggaran di Direktorat Jenderal Strategi Pertahanan dalam melaksanakan serangkaian kegiatan tertentu pada masa yang akan datang dalam hal ini Direktorat Jenderal Strategi Pertahanan sebagai unit kerja setingkat Eselon II, Kepala Sub Bagian Keuangan dan Kepala Seksi Program Eselon IV dalam merencanakan anggaran pada unit kerjanya.

Berbagai peneliti telah menguji hubungan dan pengaruh perencanaan anggaran, dalam penelitian Rosmawaty (2011) menunjukkan bahwa secara parsial perencanaan anggaran berpengaruh secara signifikan terhadap kinerja manajerial. Hal ini dapat diketahui dari nilai signifikan, dimana nilai signifikan variabel perencanaan anggaran terhadap kinerja manajerial lebih kecil dari nilai $(0,05)$.

Hasil penelitian ini mendukung penelitian Nurlaila (2008) yang melakukan penelitian pengaruh perencanaan dan pengawasan anggaran terhadap kinerja manajerial pada SKPD Kabupaten Aceh Barat. Nurlaila (2008) membuktikan secara parsial perencanaan anggaran berpengaruh signifikan namun kurang berdampak langsung terhadap peningkatan kinerja manajerial aparat pemerintahan Kabupaten Aceh Barat. Atas dasar uraian tersebut, maka penelitian ini mengajukan hipotesis pertama sebagai berikut:

H1: Perencanaan anggaran berpengaruh terhadap kinerja pegawai.

\section{Pengaruh Efektivitas terhadap Kinerja Pegawai}

Efektivitas merupakan unsur pokok untuk mencapai tujuan atau sasaran yang telah ditentukan di dalam setiap organisasi, kegiatan ataupun program. Disebut efektif apabila tercapai tujuan ataupun sasaran seperti yang telah ditentukan. Hal ini sesuai dengan pendapat H. Emerson yang dikutip Soewarno Handayaningrat S (2006:16) yang menyatakan bahwa efektivitas adalah pengukuran dalam arti tercapainya tujuan yang telah ditentukan sebelumnya.

Peningkatan efektivitas dan efisiensi kerja diharapkan sebagai wujud terlaksananya pencapaian tujuan organisasi. Untuk meningkatkan kinerja pegawai adalah dengan memperbaiki efektivitas kerja dan efisiensi dalam mencapai hasil-hasil kerja yang telah ditetapkan.

H2: Efektifitas berpengaruh terhadap kinerja pegawai.

\section{Pengaruh Optimalisasi Daya Serap terhadap Kinerja Pegawai}

Optimalisasi daya serap anggaran merupakan kemampuan untuk dapat mengestimasi anggaran belanja sesuai 
dengan kegiatan belanja yang pada akhirnya meningkatkan kualitas pelayanan publik. Secara lebih dalam kinerja juga dijelaskan sebagai pencapaian pegawai di luar tupoksi yang melekat padanya, sehingga dapat menciptakan produktifitas yang lebih baik. Hal tersebut sejalan dengan pendapat Cushway (2002) kinerja adalah menilai bagaimana seseorang telah bekerja dibandingkan dengan target yang telah ditentukan. Dalam kajian tersebut, tindakan nyata dari setiap pegawai merupakan suatu proses untuk mencapai kinerja yang baik. Kinerja merupakan keadaan yang terlaporkan, transparan dan dikonfirmasi kepada pihak-pihak tertentu untuk mengetahui keberhasilan dalam mencapai visi lembaga, serta mengetahui dampak negatif serta positif dari suatu operasional kebijakan. Dasar untuk menilai kinerja yang tinggi untuk suatu individu adalah disiplin, efektif serta efisien dalam melaksanakan tugas.

Berdasarkan penelitian yang telah dilakukan Adi Priatno (2013) faktor kinerja pegawai mempunyai pengaruh yang signifikan terhadap penyerapan anggaran pada satuan kerja dalam instansi pemerintahan. Akan tetapi perencanaan satuan kerja yang masih buruk dalam pelaksanaan kegiatan mempunyai kecenderungan memperlambat penyerapan anggaran satuan kerja. Faktor-faktor tersebut antara lain waktu penyusunan dan penelaahan anggaran terlalu pendek, pejabat pengelola keuangan sering di mutasi, pelaksanaan kegiatan tidak melihat jadwal dalam DIPA, adanya blokir (tanda bintang) pagu alokasi anggaran, dan keterlambatan penunjukan panitia pengadaan barang dan jasa. Faktor pengadaan barang dan jasa satuan kerja yang buruk dalam pelaksanaan kegiatan mempunyai kecenderungan memperlambat penyerapan anggaran satuan kerja. Kurangnya kemauan pegawai sebagai panitia pengadaan barang dan jasa, tidak sebandingnya besarnya resiko dan upah yang diterima panitia pengadaan barang dan jasa, serta adanya birokrat dalam lingkungan satuan kerja menjadi penyebab buruknya faktor pengadaan barang dan jasa pada satuan kerja. Atas dasar uraian tersebut, maka penelitian ini mengajukan hipotesis ketiga sebagai berikut

H3: Optimalisasi daya serap anggaran berpengaruh terhadap kinerja pegawai.

Berdasarkan landasan teori dan masalah penelitian, maka peneliti mengembangkan kerangka konsep penelitian yang akan diuji secara simultan dan parsial sebagaimana terlihat pada gambar.

Gambar 1

Kerangka/Konstelasi

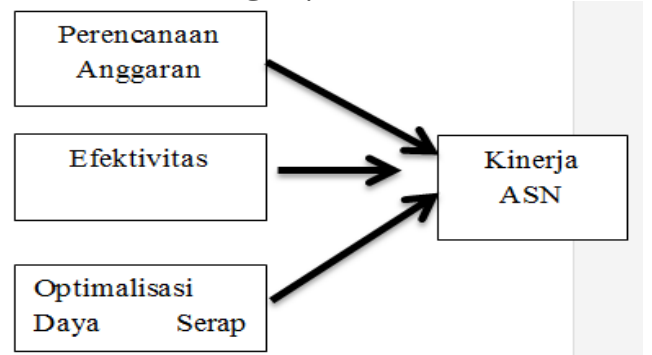

Penelitian ini berupa pengujian hipotesis variabel perencanaan, efektivitas, dan optimalisasi daya serap anggaran terhadap kinerja pegawai, dengan metode regresi linier ganda. Model pengujian tersebut adalah sebagai berikut:

$\mathrm{Y}=\mathrm{a}+\mathrm{b} 1 \mathrm{X} 1+\mathrm{b} 2 \mathrm{X} 2+\mathrm{b} 3 \mathrm{X} 3$

$\mathrm{X} 1=$ Perencanaan

$\mathrm{X} 2$ = Efektivitas

X3 = Optimalisasi daya serap

$\mathrm{Y}=$ Kinerja Pegawai

$\mathrm{a}=$ Konstanta

b1 = Koefisien Regresi Perencanaan

b2 = Koefisien Regresi Efektivitas

b3 = Koefisien Regresi Optimalisasi daya serap

\section{METODE PENELITIAN \\ Sampel Penelitian}

Populasi yang menjadi penelitian ini adalah pegawai di Direktorat Jenderal Strategi Pertahanan Kementerian Pertahanan, dengan rata rata pegawai berkisar 62 orang selama satu hari yang diperoleh dari hasil pra penelitian dengan bertanya langsung kepada pegawai Direktorat Jenderal Pertahanan Kementerian Pertahanan. Sampel adalah 
bagian (subset) dari populasi yaitu sejumlah orang, peristiwa, benda, atau obyek tertentu yang dipilih dari populasi untuk mewakili populasi tersebut (Mulyanto dan Wulandari, 2010:100) Sampel pada penelitian ini adalah sebagian dari 62 pegawai Direktorat Jenderal Strategi Pertahanan. Jumlah sampel ditentukan dengan rumus Slovin (Mulyanto dan Wulandari, 2010:103) dengan margin error $5 \%$.

\section{Metode Analisis}

Teknik pengumpulan data dengan cara pendistribusian kuesioner yaitu pertanyaan tertulis yang diajukan kepada responden dalam bentuk pertanyaan tertentu. Angket tersebut akan menggunakan alat skala likert yang terdiri dari beberapa pertanyaan yang berhubungan dengan perencanaan, efektivitas dan optimalisasi daya serap angaran terhadap kinerja pegawai.

\section{HASIL DAN PEMBAHASAN \\ Hasil Penelitian Variabel Perencanaan}

Dapat diketahui nilai rata-rata terendah untuk variabel perencanaan adalah pernyataan no 4 yaitu sebesar 4,00 dan nilai rata-rata tertinggi untuk variabel perencanaan adalah pernyataan no 2 yaitu sebesar 4,24. Nilai rata-rata variabel perencanaan adalah 4,06 $(20,32 / 5=4,06)$. Kemudian nilai yang paling sering muncul adalah 5. Yang berarti mayoritas responden memberikan nilai 5.

\section{Variabel Efektivitas}

Dapat diketahui nilai rata-rata terendah untuk variabel perencanaan adalah pernyataan no 3 yaitu sebesar 4,24 dan nilai rata-rata tertinggi untuk variabel efektivitas adalah pernyataan no 1 yaitu sebesar 4,58. Nilai rata-rata variabel perencanaan adalah 16,74 $(21,74 / 5=16,74)$. Kemudian nilai yang paling sering muncul adalah 5 . Yang berarti mayoritas responden memberikan nilai 5 .

\section{Variabel Optimalisasi Daya Serap Anggaran}

Dapat diketahui nilai rata-rata terendah untuk variabel perencanaan adalah pernyataan no 3 yaitu sebesar 3,86 dan nilai rata-rata tertinggi untuk variabel optimalisasi daya serap anggaran adalah pernyataan no 1 yaitu sebesar 4,58. Nilai rata-rata variabel perencanaan adalah 3,69 (19,82/5= 3,69 ). Kemudian nilai yang paling sering muncul adalah 4. Yang berarti mayoritas responden memberikan nilai 5 .

\section{Variabel Kinerja Pegawai}

Dapat diketahui nilai rata-rata terendah untuk variabel perencanaan adalah pernyataan no 3 yaitu sebesar 3,54 dan nilai rata-rata tertinggi untuk variabel kinerja pegawai adalah pernyataan no 1 yaitu sebesar 4,04. Nilai rata-rata variabel perencanaan adalah $3,76(18,84 / 5=3,76)$. Kemudian nilai yang paling sering muncul adalah 4 . Yang berarti mayoritas responden memberikan nilai 5 .

\section{Uji Normalitas}

Gambar 2

Uji Normalitas

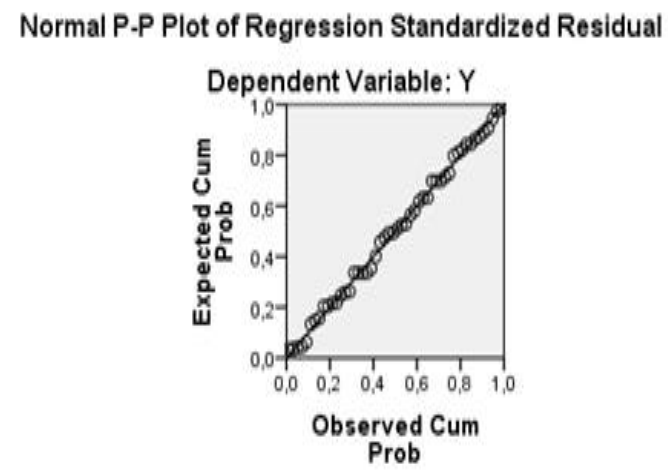

Dapat dilihat bahwa pengujian normalitas secara grafik menghasilkan grafik Normal P-P Plot yang memperlihatkan titik-titik nilai residual pada grafik Normal P-P Plot menyebar di sekitar dan mengikuti arah garis diagonal. Hal ini menunjukkan bahwa data variabel yang digunakan untuk analisis regresi ganda berasal dari data yang berdistribusi normal. 


\section{Uji Heterosdastisitas}

Gambar 3

Uji Heterosdastisitas

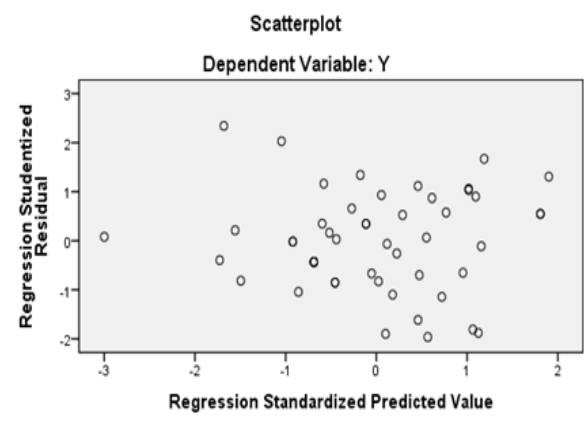

Grafik scatter plot bahwa titik-titik hasil perhitungan menyebar secara acak di atas dan di bawah titik origin serta tidak membentuk pola tertentu. Hal ini dapat dikatakan bahwa hasil analisis regresi ganda benar-benar linier karena tidak memiliki masalah heteroskedastisitas sehingga analisis regresi linier ganda dapat dilanjutkan.

\section{Analisis Regresi Linier Berganda}

Nilai-nilai koefisien dapat dilihat pada tabel 4.7 dan dimasukkan pada persamaan sebagai berikut:

$$
\mathrm{Y}=7,078+0,306 \mathrm{X} 1+0,460 \mathrm{X} 2+
$$
$0,490 \times 3$

Maka model regresi berganda tersebut diinpretasikan sebagai berikut:

1. Koefisien regresi untuk variabel Perencanaan (X1) bernilai positif, menunjukkan adanya hubungan yang searah antara perencanaan (X1) terhadap kinerja pegawai $(\mathrm{Y})$.

2. Koefisien regresi untuk Efektivitas (X2) bernilai positif dan ada hubungan yang searah antara efektifitas (X2) terhadap kinerja pegawai $(\mathrm{Y})$.

3. Koefisien regresi untuk variabel optimalisasi daya serap anggaran (X3) bernilai positif, menunjukkan adanya hubungan yang searah antara optimalisasi daya serap anggaran (X3) terhadap kinerja pegawai (Y).

\section{Uji Koefisien Determinasi}

Besarnya nilai $R$ Square adalah 0,873 atau $87,3 \%$. Hal ini menunjukkan bahwa $87,3 \%$ variabel kinerja pegawai dapat dijelaskan oleh variabel perencanaan, efektivitas dan optimalisasi daya serap anggaran. Sedangkan sisanya
$37,3 \%$ dijelaskan oleh faktor lain yang tidak dijelaskan dalam penelitian ini.

\section{Anova (Uji F)}

Nilai $F$ sebesar 49,099 dengan tingkat signifikansi sebesar 0,000. F tabel dapat dilihat pada tabel statistik pada tingkat signifikansi 0,05 dengan df $1(\mathrm{k}-$ 1) atau 3- $1=2$, dan df $2(\mathrm{n}-\mathrm{k})$ atau 50 $-3=47$ ( $\mathrm{n}$ adalah jumlah data dan $\mathrm{k}$ adalah jumlah variabel independen dan dependen), hasil diperoleh untuk $\mathrm{F}$ tabel sebesar 3,15. Sehingga penelitian ini memiliki tingkat signifikansi lebih kecil dari $0,05(0,000<0.05)$ dan F-hitung lebih besar dari F-tabel $(49,099>3.09)$, maka model regresi menjelaskan adanya pengaruh perencanaan, efektivitas, dan optimalisasi daya serap anggaran terhadap kinerja pegawai secara bersama-sama.

\section{Pengujian Hipotesis 1}

Hipotesis pertama yang diajukan dalam penelitian ini adalah terdapat pengaruh perencanaan, efektifitas, dan optimalisasi daya serap anggaran terhadap kinerja pegawai. Pengaruhnya ditunjukkan oleh nilai koefisien regresi perencanaan $(\mathrm{X} 1)$ sebesar $\mathrm{b} 1=0,306$ pada model persamaan regresi linier ganda $\mathrm{Y}=7,078+0,306 \mathrm{X} 1+0,406 \mathrm{X} 2+$ $0,490 \mathrm{X} 3$. Hipotesis statistik yang diajukan adalah sebagai berikut:

H1o: $\mathrm{b} 1=0$ : tidak ada pengaruh

H2a: $b 1 \neq 0$ : ada pengaruh

Koefisien regresi kualitas produk (X1) sebesar b1 $=0,306$ memiliki nilai probabilitas $t$ hitung sebesar 0,000 . Karena $\mathrm{b} 1 \neq 0$ dan probabilitas $\mathrm{t}$ hitung lebih kecil daripada taraf uji penelitian (sig $\mathrm{t}<\mathrm{a}$ atau $0,000<0,05)$, maka $\mathrm{H} 1 \mathrm{o}$ ditolak dan $\mathrm{H} 1 \mathrm{a}$ diterima yang berarti pengaruh perencanaan (X1) terhadap kinerja pegawai $(\mathrm{Y})$ adalah signifikan. Signifikansi hasil pengujian menunjukkan bahwa hipotesis pertama penelitian ini diterima yang berarti bahwa terdapat pengaruh parsial perencanaan terhadap kinerja pegawai.

\section{Pengujian Hipotesis 2}

Hipotesis kedua yang diajukan dalam penelitian ini adalah terdapat pengaruh efektivitas terhadap kinerja 
pegawai. Pengaruhnya ditunjukkan oleh nilai koefisien regresi efektivitas (X2) sebesar b2 $=0,406$ pada model persamaan regresi linier ganda $\mathrm{Y}=7,078$ $+0,306 \mathrm{X} 1+0,406 \mathrm{X} 2+0,490 \mathrm{X} 3$. Hipotesis statistik yang diajukan adalah sebagai berikut:

H1o: $\mathrm{b} 2=0$ : tidak ada pengaruh

$\mathrm{H} 2 \mathrm{a}: \mathrm{b} 2 \neq 0$ : ada pengaruh

Koefisien regresi efektivitas (X2) sebesar b2 $=0,406$ memiliki nilai probabilitas $t$ hitung sebesar 0,000. Karena $\mathrm{b} 2 \neq 0$ dan probabilitas $\mathrm{t}$ hitung lebih kecil daripada taraf uji penelitian ( sig $\mathrm{t}<\mathrm{a}$ atau 0,000 $<0,05$ ), maka H1o ditolak dan H1a diterima yang berarti pengaruh efektivitas (X2) terhadap kinerja pegawai $(\mathrm{Y})$ adalah signifikan. Signifikansi hasil pengujian menunjukkan bahwa hipotesis ke dua penelitian ini diterima yang berarti bahwa terdapat pengaruh parsial pengaruh efektivitas terhadap kinerja pegawai.

\section{Pengujian Hipotesis 3}

Hipotesis ketiga yang diajukan dalam penelitian ini adalah terdapat pengaruh optimalisasi daya serap anggaran terhadap kinerja pegawai. Pengaruhnya ditunjukkan oleh nilai koefisien regresi optimalisasi daya serap anggaran (X3) sebesar b3 $=0,490$ pada model persamaan regresi linier ganda $\mathrm{Y}=$ $7,078+0,306 \mathrm{X} 1+0,406 \mathrm{X} 2+0,490 \mathrm{X} 3$. Hipotesis statistik yang diajukan adalah sebagai berikut:

H1o: $\mathrm{b} 3=0$ : tidak ada pengaruh

$\mathrm{H} 2 \mathrm{a}: \mathrm{b} 3 \neq 0$ : ada pengaruh

Koefisien regresi efektivitas sebesar $\mathrm{b} 3=0,490$ memiliki nilai probabilitas $t$ hitung sebesar 0,000 . Karena $b 3 \neq 0$ dan probabilitas t hitung lebih kecil daripada taraf uji penelitian (sig $\mathrm{t}<\mathrm{a}$ atau 0,000 $<0,05$ ), maka H1o ditolak dan $\mathrm{H} 1 \mathrm{a}$ diterima yang berarti pengaruh efektivitas (X3) terhadap kinerja pegawai (Y) adalah signifikan. Signifikansi hasil pengujian menunjukkan bahwa hipotesis kedua penelitian ini diterima yang berarti bahwa terdapat pengaruh parsial pengaruh efektivitas terhadap kinerja pegawai.

\section{Pembahasan \\ Pengaruh \\ Perencanaan \\ terhadap Kinerja Pegawai}

Perencanaan memiliki pengaruh signifikan terhadap kinerja pegawai ini ditujukan bahwa pada variabel perencanaan diperoleh $t$ hitung sebesar 3,485 dengan nilai signifikan sebesar 0,000 lebih kecil dari $0,05(0,000<0,05)$, dan koefisien regresi mempunyai nilai positif sebesar 0,306 atau sebesar 30,6\%. Maka penelitian ini berhasil membuktikan hipotesis pertama yang menyatakan bahwa perencanaan berpengaruh positif terhadap kinerja pegawai pada Direktoran Jenderal Strategi Pertahanan. Artinya makin tinggi perencanaan yang diterima pegawai maka makin tinggi pula kinerja pegawai.

\section{Pengaruh Efektivitas terhadap Kinerja Pegawai}

Hasil penelitian menujukkan bahwa pada variabel efektivitas diperoleh nilai $t$ hitung 5,675 dengan nilai signifikan sebesar 0,000 lebih kecil 0,05 $(0,000<0,05)$ dan koefisien regresi mempunyai nilai positif sebesar 0,406 , maka penelitian ini berhasil membuktikan hipotesis kedua yang menyatakan bahwa efektivitas berpengaruh positif terhadap kinerja pegawai di Direktorat Jenderal Strategi Pertahanan. Artinya makin tinggi efektivitas yang diterima pegawai maka makin tinggi pula kinerja pegawai.

\section{Pengaruh Optimalisasi Daya Serap Anggaran terhadap Kinerja Pegawai.}

Hasil penelitian menujukkan bahwa pada variabel optimalisasi daya serap anggaran diperoleh nilai t hitung 5,271 dengan nilai signifikan sebesar 0,000 lebih kecil $0,05 \quad(0,000<0,05)$ dan koefisien regresi mempunyai nilai positif sebesar 0,490, maka penelitian ini berhasil membuktikan hipotesis ketiga yang menyatakan bahwa optimalisasi daya serap anggaran berpengaruh positif terhadap kinerja pegawai di Direktorat Jenderal Strategi Pertahanan. Artinya makin tinggi optimalisasi daya serap anggaran yang diterima pegawai maka makin tinggi pula kinerja pegawai. 


\section{KESIMPULAN}

\section{Simpulan}

- Pengaruh perencanaan berpengaruh positif signifikan terhadap kinerja pegawai pada Direktorat Jenderal Strategi Pertahanan Kementerian Pertahanan, jika perencanaan yang bagus dan sesuai karyawan akan bekerja dengan baik sebab dengan begitu secara tidak langsung telah menambah kinerja pegawai semakin meningkat maka dari itu pegawai itu sendiri untuk melakukan pekerjaannya dengan baik.

- Pengaruh efektivitas berpengaruh positif signifikan terhadap kinerja pegawai pada Direktorat Jenderal Strategi Pertahanan Kementerian Pertahanan, dengan arah positif yang artinya jika efektivitas semakin baik maka kinerja pegawai semakin meningkat.

- Pengaruh optimalisasi daya serap anggaran berpengaruh dan signifikan terhadap kinerja pegawai pada Direktorat Jenderal Strategi Pertahanan Kementerian Pertahanan, dengan arah koefisien positif yang artinya jika optimalisasi daya serap anggaran yang bagus maka semakin baik pula kinerja pegawai.
DAFTAR PUSTAKA

Barry, Cushway. (2002). Human Resource Management. Jakarta: PT. Gramedia.

Handayaningrat, Soewarno. (1990). Pengantar Study Administrasi Dan Manajemen. Jakarta: CV. Haji Masagung.

Kasmir. (2010). Pengantar Manajemen Keuangan. Jakarta: Kencana Prenada Media Group.

Kurniawan, Agung. (2005). Transformasi Pelayanan Publik. Yogyakarta: Pembaharuan.

Mangkunegara, Anwar Prabu. (2000). Manajemen Sumber Daya Manusia Perusahaan, Bandung: PT. Remaja Rosda Karya.

Mulyanto, H dan A. Wulandari. (2010). Penelitian: Metode dan Analisis. Semarang: CV. Agung.

Prasetyo, Adi Priatno. 2013. Analisis Faktor-Faktor yang mempengaruhi Penyerapan Anggaran Pada Satuan Kerja Lingkup Pembayaran KPPN Blitar. Jurnal. Fakultas Ekonomi dan Bisnis Universitas Brawijaya.

Sutrisno, Edi. (2009). Manajemen Sumber Daya Manusia, (1 ed). Jakarta: Kencana Prenada Media Group. 